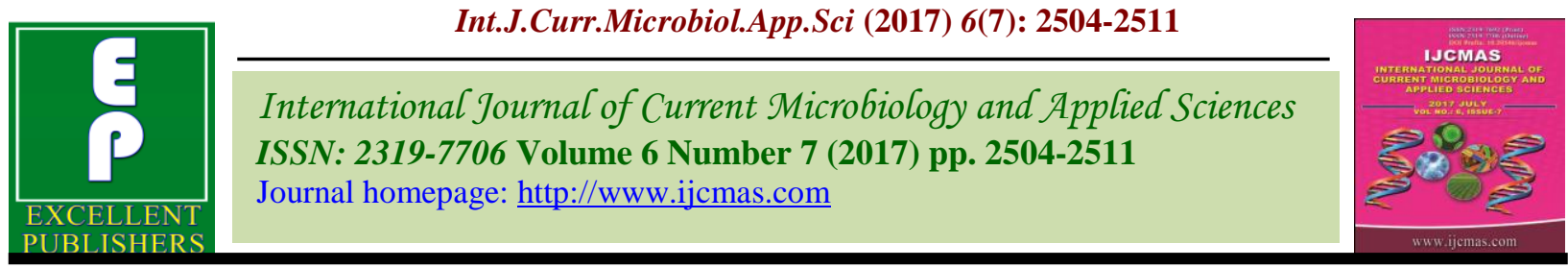

Original Research Article

https://doi.org/10.20546/ijcmas.2017.607.355

\title{
Changing Antimicrobial Susceptibility Pattern of E. coli Isolated from Urine and Pus Samples
}

\author{
Mita D. Wadekar and J.V. Sathish* \\ Department of Microbiology, Chamarajanagar Institute of Medical Sciences, \\ Chamarajanagar, Karnataka, India \\ *Corresponding author
}

\begin{abstract}
A B S T R A C T
Antimicrobial resistance in $E$. coli is of major concern worldwide due to its increasing

Keywords

E. coli,

Antimicrobial

susceptibility,

Amikacin,

Gentamicin.

Article Info

Accepted:

26 June 2017

Available Online:

10 July 2017 resistance to several commonly prescribed antibiotics. The aim of this study was to determine the antimicrobial susceptibility pattern of $E$. coli. A retrospective analysis of $E$. coli and their antimicrobial susceptibility was done on urine and pus samples at Subbaiah Institute of Medical Sciences, Shimoga. Antibiotic susceptibility was tested on Mueller Hinton agar by Kirby Bauer disc diffusion method. Total of $73 \mathrm{E}$. coli isolates from urine sample were studied. Females $55(75 \%)$ were more susceptible to urinary tract infections (UTIs) than males18 (25\%). Majority of the isolates were sensitive to amikacin 69 (95\%), gentamicin $55(75 \%)$ and nitrofurantoin $65(89 \%)$. Out of 28 isolates from pus sample, 19 $(68 \%)$ were from males and $9(32 \%)$ from females. Most of the isolates were sensitive to amikacin 25 (89\%), gentamicin 21 (75\%), meropenem 21 (75\%) and chloramphenicol 20 (71\%). Resistance rates to ampicillin and cephalosporins were high. Since most isolates were sensitive to amikacin and gentamicin in both samples, they are considered as appropriate antibiotics for treatment of $E$. coli infections.
\end{abstract}

\section{Introduction}

Escherichia coli (E. coli) is the most significant species in the genus Escherichia (Naheed Akhtar Khan et al., 2002). E. coli is a common inhabitant of the human and animal gut, but can also be found in water, soil and vegetation (Kibret et al., 2011). It is the leading pathogen causing urinary tract infections and is among the most common pathogens causing blood stream infections, wound infection, otitis media and other complications in humans (Gautam et al., 2013).

Urinary tract infection (UTI) is defined as presence and active multiplication of microorganisms within the urinary tract and is one of the commonest bacterial infections seeking treatment in clinical practice (Banerjee et al., 2009). Pyogenic infection is characterized by several local inflammations, usually with pus formation, generally caused by one of the pyogenic bacteria, which can produce the accumulation of dead leukocytes and infectious agent commonly known as pus (Vijeta Sharma et al., 2015). Most of these infections are caused by Gram-negative bacteria like Escherichia coli (E. coli), Klebsiella spp., Proteus mirabilis, Pseudomonas aeruginosa, Acinetobacter spp., and Serratia spp. and Gram-positive bacteria 
such as Enterococcus spp. and Staphylococcus spp. (Mulugeta Kibret et al., 2014). E. coli is one of the most frequently isolated organisms from urine and pus samples. These strains are often multi drug resistant, i.e. refractory to 3 or more different classes of antibiotic agents (Sayan Bhattacharyya et al., 2015). They are the frequent cause of morbidity in outpatients as well as most frequently involved in the cause of nosocomial infection in many hospitals (Shanthi et al., 2012).

Production of beta-lactamases is the principal mechanism of resistance to beta-lactam antibiotics among members of the Enterobacteriaceae family (Mohanalakshmi et al., 2014). Three major groups of such enzymes are usually distinguished, class $\mathrm{C}$ cephalosporinases (AmpC), extended spectrum beta-lactamases (ESBLs) and metallobeta-lactamases (MBLs), are of great concern (Fam et al., 2006). These enzymes hydrolyze the amide bond of the four membered characteristic beta - lactam ring, thus rendering the antimicrobial ineffective (Prashant Durwas Peshattiwar et al., 2011). Bacteria carrying such enzymes are the important cause of multi-drug resistant infections throughout the world and also the incidence of such organisms appear to be increasing in the community (Nwosu et al., 2014).

Drug resistance of pathogens is a serious medical problem, because of very fast arise and spread of mutant strains that are insusceptible to medical treatment. Microorganisms use varied mechanisms to acquire drug resistance viz. horizontal gene transfer (plasmids, transposons and bacteriophages), recombination of foreign DNA in bacterial chromosome and mutations in different chromosomal locus (Jahangir Alam et al., 2013). Infections due to multi drug resistant (MDR) E. coli increases the cost of treatment, morbidity and mortality especially in developing countries like India (Siddarth Surwonse et al., 2017). Hence the present study was conducted to detect such resistant $E$. coli and to know their susceptibility pattern.

\section{Materials and Methods}

\section{Data analysis}

A retrospective analysis of $E$. coli isolates of urine and pus samples was performed at Subbaiah Institute of Medical Sciences, Shimoga. The sex, age and outpatient/ Inpatient details of patients, number of $E$. coli isolates and their antimicrobial susceptibility profiles were collected from the records. The data were entered into Excel for analysis. As the study was based on secondary data there were no ethical issues.

\section{Sample collection and processing}

As per the standard operation procedures, pus sample and clean-catch midstream urine specimens were collected. Samples were plated on MacConkey agar and, blood agar and then incubated aerobically at $37^{\circ} \mathrm{C}$ for 24 h. From positive cultures, pathogens were identified according to the standard operational procedures as per the standard microbiological methods (Collee et al., 2007). In urine samples, a significant bacterium was considered if culture yield $\geq 10^{5} \mathrm{CFU} / \mathrm{mL}$.

\section{Antimicrobial susceptibility testing}

According to the standard operational procedures, antimicrobial susceptibility tests were done on Mueller-Hinton agar using Kirby-Bauer disk diffusion method. The antimicrobial agents tested were: ampicillin $(10 \mu \mathrm{g})$, amoxyclav $(20 / 10 \mu \mathrm{g})$, gentamycin $(10 \mu \mathrm{g})$, amikacin $(30 \mu \mathrm{g})$, ciprofloxacin $(10 \mu \mathrm{g})$, norfloxacin $(10 \mu \mathrm{g})$, cotrimoxazole 
$(1.25 / 23.75 \mu \mathrm{g}), \quad$ ceftazidime $(30 \mu \mathrm{g})$, ceftriaxone $(30 \mu \mathrm{g})$, cefotaxime $(30 \mu \mathrm{g})$, cefuroxime $(30 \mu \mathrm{g})$, cefoxitin $(30 \mu \mathrm{g})$, cefipime $(30 \mu \mathrm{g}), \quad$ aztreonam $(30 \mu \mathrm{g}), \quad$ meropenem $(30 \mu \mathrm{g})$, piperacillin $(100 \mu \mathrm{g})$, chloramphenicol $(300 \mu \mathrm{g})$, tetracycline $(30 \mu \mathrm{g})$. Resistance data were interpreted according to Clinical laboratory Standards Institute (CLSI, 2017).

\section{Results and Discussion}

Of 73 E. coli isolates from urine sample, 55 $(75 \%)$ were from females and $18(25 \%)$ from males and $49(67 \%)$ isolates were from outpatient department and 24 (33\%) from inpatient. The age $18-45$ years $37(51 \%)$ in case of urine isolates and age of $>45$ years $18(64 \%)$ in case of pus isolates were the most affected group. Majority of the isolates were sensitive to amikacin 69 (95\%), gentamicin $55(75 \%)$ and nitrofurantoin $65(89 \%)$. Out of 28 isolates from pus sample, $19(68 \%)$ were from males and 9 (32\%) from females and 7 $(25 \%)$ isolates were from outpatient department and 21 (75\%) from inpatient. Most of the isolates were sensitive to amikacin 25 (89\%), gentamicin $21(75 \%)$, meropenem $21(75 \%)$ and chloramphenicol $20(71 \%)$. In both the samples, resistance rate to ampicillin and all cephalosporins were high (Table 1-4).

Indeed, members of E. coli are widely distributed in the environment and cause a variety of infections in the hospital and community settings (Marwa Aly et al., 2012). UTIs and pyogenic infections are among the most common diseases diagnosed worldwide. About 150 million people are diagnosed with UTI each year and about $80 \%$ of UTIs are caused by E. coli (Reem Fouad Polse et al., 2016). Availability of new antimicrobials has improved the management of UTIs. However, the management of UTI infections has been jeopardized by increase in immergence of antimicrobial drug resistance (Mulugeta Kibret et al., 2014).
In this study, more isolates from urine samples were recovered from females $55(75 \%)$ as compared to males $18(25 \%)$ due to a short urethra and its proximity to the anal opening, which correlated with the study of Yashwant Kumar et al., (2013). In case of pus samples, highest isolates were observed in male $19(68 \%)$ as compared to female $9(32 \%)$. It was correlated with Vijeta Sharma et al., (2015) study which shows male preponderance $(55 \%)$. Maximum number of patients belonged to age group 18-45 years $37(51 \%)$ in case of urine isolates and to age group of $>45$ years $18(64 \%)$ in case of pus isolates. Findings were compared to other authors like Mulugeta Kibret et al., (2014) showed similar results. In urine sample, OP isolates were 49(67\%) and IP 24(33\%) and in pus sample, OP isolates were $7(25 \%)$ and IP 21(75\%).

Antimicrobial resistance among $E$. coli shows considerable variations during different time periods and in different areas. The problem becomes further complicated with the emergence of beta-lactamase producing $E$. coli. It is of major concern worldwide due to its increasing resistance to several commonly prescribed antibiotics. E. coli isolates varied in their susceptibility to different antibiotics belonging to different groups. From the result of our study, most of the urine isolates were sensitive to amikacin $69(95 \%)$, gentamicin $55(75 \%)$ and nitrofurantoin $65(89 \%)$ and pus isolates to amikacin $25(89 \%)$, gentamicin 21 (75\%), meropenem $21 \quad(75 \%)$ and chloramphenicol $20 \quad$ (71\%). Hence, aminoglycosides and nitrofurantoin in case of UTI and meropenem, chloramphenicol in case of pyogenic infections could be considered as a choice for treatment. This result correlated with study done by Rebecca Naveen et al., (2005). Susceptibility to nitrofurantoin has remained practically unchanged since its introduction into clinical practice more than 50 years ago. 
Table.1 Age, sex and OP/IP distribution of E. coli isolates from urine sample

\begin{tabular}{|c|c|c|c|c|c|}
\hline \multirow[t]{2}{*}{ Age (years) } & \multirow{2}{*}{$\begin{array}{c}\text { No. of } \\
\text { isolates } \\
\text { NO. }(\%)\end{array}$} & \multicolumn{2}{|c|}{ Sex } & \multirow{2}{*}{$\begin{array}{c}\text { OP } \\
\text { NO. }(\%)\end{array}$} & \multirow{2}{*}{$\begin{array}{c}\text { IP } \\
\text { NO. }(\%)\end{array}$} \\
\hline & & $\begin{array}{c}\text { M } \\
\text { NO. }(\%)\end{array}$ & $\begin{array}{c}\mathbf{F} \\
\text { NO. }(\%)\end{array}$ & & \\
\hline $1-18$ & $6(8)$ & $2(3)$ & $4(6)$ & $3(4)$ & $3(4)$ \\
\hline $18-45$ & $37(51)$ & $5(7)$ & $32(43)$ & $28(38)$ & $9(12)$ \\
\hline$>45$ & $30(41)$ & $11(15)$ & $19(26)$ & $18(25)$ & $12(17)$ \\
\hline Total & $73(100)$ & $18(25)$ & $55(75)$ & $49(67)$ & $24(33)$ \\
\hline
\end{tabular}

Table.2 Antibiotic sensitivity pattern E. coli isolates from urine sample

\begin{tabular}{|c|c|c|c|c|c|c|c|c|c|c|c|c|c|c|c|c|c|}
\hline & $\begin{array}{l}\text { AMP } \\
\text { NO. } \\
(\%)\end{array}$ & $\begin{array}{c}\text { AMC } \\
\text { NO. } \\
(\%)\end{array}$ & $\begin{array}{c}\text { G } \\
\text { NO. } \\
(\%)\end{array}$ & $\begin{array}{l}\text { AK } \\
\text { NO. } \\
(\%)\end{array}$ & $\begin{array}{l}\text { NET } \\
\text { NO. } \\
(\%)\end{array}$ & $\begin{array}{l}\text { CIP } \\
\text { NO. } \\
(\%)\end{array}$ & $\begin{array}{l}\text { NX } \\
\text { NO. } \\
(\%)\end{array}$ & $\begin{array}{c}\text { COT } \\
\text { NO. } \\
(\%)\end{array}$ & $\begin{array}{l}\text { NIT } \\
\text { NO. } \\
(\%)\end{array}$ & $\begin{array}{c}\text { CAZ } \\
\text { NO. } \\
(\%)\end{array}$ & $\begin{array}{l}\text { CTR } \\
\text { NO. } \\
(\%)\end{array}$ & $\begin{array}{c}\text { CTX } \\
\text { NO. } \\
(\%)\end{array}$ & $\begin{array}{c}\text { CXM } \\
\text { NO. } \\
(\%)\end{array}$ & $\begin{array}{l}\text { CN } \\
\text { NO. } \\
(\%)\end{array}$ & $\begin{array}{c}\text { CPM } \\
\text { NO. } \\
(\%)\end{array}$ & $\begin{array}{l}\text { AT } \\
\text { NO. } \\
(\%)\end{array}$ & $\begin{array}{c}\text { MRP } \\
\text { NO. } \\
(\%)\end{array}$ \\
\hline $\begin{array}{c}\text { OP } \\
\text { isolates (49) }\end{array}$ & $\begin{array}{c}8 \\
(16)\end{array}$ & $\begin{array}{c}11 \\
(22)\end{array}$ & $\begin{array}{c}39 \\
(80)\end{array}$ & $\begin{array}{c}47 \\
(96)\end{array}$ & $\begin{array}{c}42 \\
(86)\end{array}$ & $\begin{array}{c}17 \\
(35)\end{array}$ & $\begin{array}{c}15 \\
(31)\end{array}$ & $\begin{array}{c}24 \\
(49)\end{array}$ & $\begin{array}{c}44 \\
(90)\end{array}$ & $\begin{array}{c}13 \\
(27)\end{array}$ & $\begin{array}{c}13 \\
(27)\end{array}$ & $\begin{array}{c}13 \\
(27)\end{array}$ & $\begin{array}{c}13 \\
(27)\end{array}$ & $\begin{array}{c}22 \\
(45)\end{array}$ & $\begin{array}{c}12 \\
(24)\end{array}$ & $\begin{array}{c}13 \\
(27)\end{array}$ & $\begin{array}{c}31 \\
(63)\end{array}$ \\
\hline$\underset{\text { isolates(24) }}{\text { IP }}$ & $\begin{array}{c}2 \\
(8)\end{array}$ & $\begin{array}{c}5 \\
(21)\end{array}$ & $\begin{array}{c}16 \\
(67)\end{array}$ & $\begin{array}{c}22 \\
(92)\end{array}$ & $\begin{array}{c}20 \\
(83)\end{array}$ & $\begin{array}{c}4 \\
(17)\end{array}$ & $\begin{array}{c}6 \\
(25)\end{array}$ & $\begin{array}{c}10 \\
(42)\end{array}$ & $\begin{array}{c}21 \\
(88)\end{array}$ & $\begin{array}{c}3 \\
(13)\end{array}$ & $\begin{array}{c}3 \\
(13)\end{array}$ & $\begin{array}{c}3 \\
(13)\end{array}$ & $\begin{array}{c}3 \\
(13)\end{array}$ & $\begin{array}{c}11 \\
(46)\end{array}$ & $\begin{array}{c}9 \\
(38)\end{array}$ & $\begin{array}{c}3 \\
(13)\end{array}$ & $\begin{array}{c}14 \\
(58)\end{array}$ \\
\hline Total (73) & $\begin{array}{c}10 \\
(14)\end{array}$ & $\begin{array}{c}16 \\
(22)\end{array}$ & $\begin{array}{c}55 \\
(75)\end{array}$ & $\begin{array}{c}69 \\
(95)\end{array}$ & $\begin{array}{c}62 \\
(85)\end{array}$ & $\begin{array}{c}21 \\
(29)\end{array}$ & $\begin{array}{c}21 \\
(29)\end{array}$ & $\begin{array}{c}34 \\
(47)\end{array}$ & $\begin{array}{c}65 \\
(89)\end{array}$ & $\begin{array}{c}16 \\
(22)\end{array}$ & $\begin{array}{c}16 \\
(22)\end{array}$ & $\begin{array}{c}16 \\
(22)\end{array}$ & $\begin{array}{c}16 \\
(22)\end{array}$ & $\begin{array}{c}33 \\
(45)\end{array}$ & $\begin{array}{c}26 \\
(36)\end{array}$ & $\begin{array}{c}16 \\
(22)\end{array}$ & $\begin{array}{l}45 \\
62\end{array}$ \\
\hline
\end{tabular}

Table.3 Age, sex and OP/IP distribution of E. coli isolates from pus sample

\begin{tabular}{|c|c|c|c|c|c|}
\hline \multirow[t]{2}{*}{ Age (years) } & \multirow{2}{*}{$\begin{array}{c}\text { No. of } \\
\text { isolates } \\
\text { NO. }(\%)\end{array}$} & \multicolumn{2}{|c|}{ Sex } & \multirow{2}{*}{$\begin{array}{c}\text { OP } \\
\text { NO. }(\%)\end{array}$} & \multirow{2}{*}{$\begin{array}{c}\text { IP } \\
\text { NO. }(\%)\end{array}$} \\
\hline & & $\begin{array}{c}\text { M } \\
\text { NO. }(\%)\end{array}$ & $\begin{array}{c}\text { F } \\
\text { NO. }(\%)\end{array}$ & & \\
\hline $1-18$ & $2(7)$ & - & $2(7)$ & $2(7)$ & - \\
\hline $18-45$ & $8(29)$ & $6(22)$ & $2(7)$ & $4(14)$ & $4(14)$ \\
\hline$>45$ & $18(64)$ & $13(46)$ & $5(18)$ & $1(4)$ & $17(61)$ \\
\hline Total & $28(100)$ & 19(68) & $9(32)$ & $7(25)$ & $21(75)$ \\
\hline
\end{tabular}


Table.4 Antibiotic sensitivity pattern E. coli isolates from pus sample

\begin{tabular}{|c|c|c|c|c|c|c|c|c|c|c|c|c|c|c|c|c|c|c|}
\hline & $\begin{array}{c}\text { AMP } \\
\text { NO. } \\
(\%)\end{array}$ & $\begin{array}{c}\text { AMC } \\
\text { NO. } \\
(\%)\end{array}$ & $\begin{array}{c}\mathbf{G} \\
\text { NO. } \\
(\%)\end{array}$ & $\begin{array}{c}\text { AK } \\
\text { NO. } \\
(\%)\end{array}$ & $\begin{array}{l}\text { CIP } \\
\text { NO. } \\
(\%)\end{array}$ & $\begin{array}{l}\text { NX } \\
\text { NO. } \\
(\%)\end{array}$ & $\begin{array}{c}\text { COT } \\
\text { NO. } \\
(\%)\end{array}$ & $\begin{array}{c}\text { CAZ } \\
\text { NO. } \\
(\%)\end{array}$ & $\begin{array}{c}\text { CTR } \\
\text { NO. } \\
(\%)\end{array}$ & $\begin{array}{c}\text { CTX } \\
\text { NO. } \\
(\%)\end{array}$ & $\begin{array}{c}\text { CXM } \\
\text { NO. } \\
(\%)\end{array}$ & $\begin{array}{l}\text { CN } \\
\text { NO. } \\
(\%)\end{array}$ & $\begin{array}{c}\text { CPM } \\
\text { NO. } \\
(\%)\end{array}$ & $\begin{array}{c}\text { AT } \\
\text { NO. } \\
(\%)\end{array}$ & $\begin{array}{c}\text { MRP } \\
\text { NO. } \\
(\%)\end{array}$ & $\begin{array}{c}\text { PI } \\
\text { NO. } \\
(\%)\end{array}$ & $\begin{array}{c}\text { C } \\
\text { NO. } \\
(\%)\end{array}$ & $\begin{array}{c}\text { TE } \\
\text { NO. } \\
(\%)\end{array}$ \\
\hline $\begin{array}{c}\text { OP isolates } \\
\text { (7) }\end{array}$ & $\begin{array}{c}1 \\
(14)\end{array}$ & $\begin{array}{c}3 \\
(43)\end{array}$ & $\begin{array}{c}5 \\
(71)\end{array}$ & $\begin{array}{c}7 \\
(100)\end{array}$ & $\begin{array}{c}2 \\
(29)\end{array}$ & $\begin{array}{c}3 \\
(43)\end{array}$ & $\begin{array}{c}4 \\
(57)\end{array}$ & $\begin{array}{c}4 \\
(57)\end{array}$ & $\begin{array}{c}3 \\
(43)\end{array}$ & $\begin{array}{c}3 \\
(43)\end{array}$ & $\begin{array}{c}3 \\
(43)\end{array}$ & $\begin{array}{c}5 \\
(71)\end{array}$ & $\begin{array}{c}4 \\
(57)\end{array}$ & $\begin{array}{c}3 \\
(43)\end{array}$ & $\begin{array}{c}6 \\
(86)\end{array}$ & $\begin{array}{c}4 \\
(57)\end{array}$ & $\begin{array}{c}4 \\
(57)\end{array}$ & $\begin{array}{c}3 \\
(43)\end{array}$ \\
\hline $\begin{array}{l}\text { IP isolates } \\
(21)\end{array}$ & $\begin{array}{c}3 \\
(14)\end{array}$ & $\begin{array}{c}9 \\
(43)\end{array}$ & $\begin{array}{c}16 \\
(76)\end{array}$ & $\begin{array}{c}18 \\
(86)\end{array}$ & $\begin{array}{c}8 \\
(38)\end{array}$ & $\begin{array}{c}7 \\
(33)\end{array}$ & $\begin{array}{c}8 \\
(38)\end{array}$ & $\begin{array}{c}4 \\
(19)\end{array}$ & $\begin{array}{c}5 \\
(24)\end{array}$ & $\begin{array}{c}5 \\
(24)\end{array}$ & $\begin{array}{c}5 \\
(24)\end{array}$ & $\begin{array}{c}9 \\
(43)\end{array}$ & $\begin{array}{c}6 \\
(29)\end{array}$ & $\begin{array}{c}5 \\
(24)\end{array}$ & $\begin{array}{c}15 \\
(71)\end{array}$ & $\begin{array}{c}9 \\
(43)\end{array}$ & $\begin{array}{c}16 \\
(76)\end{array}$ & $\begin{array}{c}10 \\
(48)\end{array}$ \\
\hline Total (28) & $\begin{array}{c}4 \\
(14)\end{array}$ & $\begin{array}{c}12 \\
(43)\end{array}$ & $\begin{array}{c}21 \\
(75)\end{array}$ & $\begin{array}{c}25 \\
(89)\end{array}$ & $\begin{array}{c}10 \\
(36)\end{array}$ & $\begin{array}{c}10 \\
(36)\end{array}$ & $\begin{array}{c}12 \\
(43)\end{array}$ & $\begin{array}{c}8 \\
(29)\end{array}$ & $\begin{array}{c}8 \\
(29)\end{array}$ & $\begin{array}{c}8 \\
(29)\end{array}$ & $\begin{array}{c}8 \\
(29)\end{array}$ & $\begin{array}{c}14 \\
(50)\end{array}$ & $\begin{array}{c}10 \\
(36)\end{array}$ & $\begin{array}{c}8 \\
(29)\end{array}$ & $\begin{array}{c}21 \\
(75)\end{array}$ & $\begin{array}{c}13 \\
(46)\end{array}$ & $\begin{array}{c}20 \\
(71)\end{array}$ & $\begin{array}{c}13 \\
(46)\end{array}$ \\
\hline
\end{tabular}

AMP - AMPICILLIN, AMC - AMOXYCLAV, G - GENTAMYCIN, AK - AMIKACIN, CIP - CIPROFLOXACIN, NX -NORFLOXACIN, COT COTRIMOXAZOLE, CAZ - CEFTAZIDIME, CTR - CEFTRIAXONE, CTX - CEFOTAXIME, CXM - CEFUROXIME, CN - CEFOXITIN, CPM CEFIPIME, AT - AZTREONAM, MRP - MEROPENEM, PI - PIPERACILLIN, C - CHLORAMPHENICOL, TE - TETRACYCLINE 
Since standard medication with nitrofurantoin does not achieve therapeutic concentrations in the bloodstream, its use is advised only for complicated cystitis (Gautam et al., 2013). Most isolates were resistant to beta lactum antibiotics like ampicillin and cephalosporins. This result was comparable to Eze et al., (2015) study. This high resistance may be due to the spontaneous and uncontrollable use of these antibiotics. Most cases of multiple antibiotics resistant strains have been demonstrated to be due to transferable, extrachromosomal circular DNA, plasmids (Charles Okechukwu Esimone et al., 2010). Drug resistance is also common in the elderly which most likely reflects greater comorbidities, hospitalizations, and antimicrobial exposure among older patients (Sanjeev Swami et al., 2013). Several studies have documented a positive relationship between the use of third-generation cephalosporins, other $\beta$-lactams or fluoroquinolones and the acquisition of antimicrobial resistance by ESBL-producing organisms. In recent years, use of fluoroquinolones has increased in many countries and emergence of resistance of bacterial isolates to fluoroquinolones has been observed (Saghir Ahmad Jafri et al., 2014). In our study, both urine and pus isolates showed only $25 \%$ to $35 \%$ sensitivity to fluoroquinolones. Tailoring antibiograms and treatment recommendations to better match specific patient populations could improve patient care, simplify treatment regimens, improve antimicrobial stewardship, and reduce health care costs (Christian Smith et al., 2015).

In conclusion, many variations exist among $E$. coli in terms of antibiotic sensitivity pattern. Periodic formulation and review of antimicrobial policies are therefore required for controlling the development and dissemination of drug resistance. Rationales for prudent antimicrobial use, followed by discrete adherence to the same, are needed. Moreover, due to the high prevalence of variability among antibiograms, empirical selection should be based on the knowledge of local prevalence and individual sensitivity rather than on universal guidelines.

\section{References}

Banerjee, S. 2009. The study of urinary tract infections and antibiogram of uropathogens in and around Ahmadnagar, Maharashtra. The Internet J. Infect. Dis., 9(1): 1-5.

Charles Okechukwu Esimone, Chukwuemeka Sylvester Nworu, Gugu Thaddeus Harrison. 2010. Antibiogram and Plasmid Profile of Some MultiAntibiotics Resistant Urinopathogens Obtained from Local Communities of Southeastern Nigeria. Ibnosina J. Med. Biomed. Sci., 2(4): 152-159.

Christian Smith, S., Christopher Bazzoli, Irving Chung, Andrew Johnson and Daniel R. Martin. 2015. Antimicrobial Susceptibility of Escherichia coli in Uncomplicated Cystitis in the Emergency Department: Is the Hospital Antibiogram an Effective Treatment Guide? Academic Emergency Med., 22: 998-1000.

Clinical Laboratory Standards Institutes (CLSI). 2017. Performance Standards for antimicrobial susceptibility testing, XXI International Supplement (M100S27). Wayne, Pennsylvania, USA: National Committee for Clinical Laboratory Standards.

Collee, J.G., Barrie, P., Marmion, A.G. Fraser, A. Simmons. 2007. Mackie and McCartney Practical Medical Microbiology, $14^{\text {th }}$ ed. Edinburgh: Churchill Livingstone.

Eze, E.A., Agbo, E.C., Eze, C.N. 2015. Occurrence of Beta-Lactamases and the Antibiogram Pattern of Clinical Isolates 
of Escherichia coli and Klebsiella Species in Nsukka Metropolis. American J. Microbiol. Biotechnol., 2(5): 69-74.

Fam, N., M. Diab, H. Helmi and I. ElDefrawy. 2006. Phenotypic Detection of Metallo- $\beta$-Lactamases and Extended Spectrum $\beta$-Lactamases Among Gram Negative Bacterial Clinical Isolates. Egyptian J. Med. Microbiol., 15(4): 719-29.

Gautam, R., et al. 2013. Antimicrobial susceptibility patterns of Escherichia coli from various clinical sources. $J$. Chitwan Med. College, 3(3): 14-17.

Kibret, M., Abera, B. 2011. Antimicrobial susceptibility patterns of E. coli from clinical sources in northeast Ethiopia. African Health Sci., 11(S1): S40 - S45.

Marwa, E.A., Aly, Tamer, M., Essam and Magdy, A., Amin. 2012. Antibiotic Resistance Profile of E. coli Strains Isolated from Clinical Specimens and Food Samples in Egypt. Int. J. Microbiol. Res., 3(3): 176-182.

Md. Jahangir Alam, Md. Rabiul Awal, Md. Abm Sharifuzzaman, Kaniz Fatema and Mst. Saleha Sultana. 2013. Antibiogram and plasmid profiling of $E$. coli isolates and assessment of antibacterial activity of their extracellular synthesized silver nanoparticles. Curr. Res. Microbiol. Biotechnol., 1(5): 245-250.

Mohanalakshmi, et al. 2014. A report on Extended-Spectrum $\quad \beta$ - Lactamases (ESBLs) producing Escherichia coli isolated from clinical samples. Curr. Res. Microbiol. Biotechnol., 2(2): 347350.

Mulugeta Kibret and Bayeh Abera. 2014. Prevalence and antibiogram of bacterial isolates from urinary tract infections at Dessie Health Research Laboratory, Ethiopia. Asian Pac. J. Trop. Biomed., 4(2): 164-168.

Naheed Akhtar Khan, et al. 2002. Incidence and antibiogram patterns of Escherichia coli isolated from various clinical samples from patients from N.I.H Islamabad. Pak. J. Biol. Sci., 5(1): 111113.

Nwosu, L., E.S. Amadi, C.E. Nwanyanwu, C.I. Chikwendu, C.L. Madu. 2014. The prevalence of extended spectrum betalactamases (ESBLs) among Escherichia coli and Klebsiella species urinary isolates from Abia state university teaching hospital (ABSUTH) aba, Abia State Nigeria. Int. J. Microbiol. Mycol., 2(3): 20-28.

Prashant Durwas Peshattiwar and Basavaraj Virupaksappa Peerapur. 2011. ESBL and MBL Mediated Resistance in Pseudomonas aeruginosa. J. Clin. Diag. Res., 5(8): 1552-1554.

Rebecca Naveen and Elizabeth Mathai. 2005. Some virulence characteristics of uropathogenic Escherichia coli in different patient groups. Indian J. Med. Res., 122: 143-147.

Reem Fouad Polse, Samira Younis Yousif, Mahde Saleh Assafi. 2016. Prevalence and antimicrobial susceptibility patterns of uropathogenic E. coli among people in Zakho, Iraq. Int. J. Res. Med. Sci., 4(4): 1219-1223.

Saghir Ahmad Jafri, Muhammad Qasim, Muhammad, S., Masoud, Mahmood-urRahman, Mateen Izhar and Saqib Kazmi. 2014. Antibiotic resistance of $E$. coli isolates from urine samples of Urinary Tract Infection (UTI) patients in Pakistan. Bioinformation, 10(7): 419422.

Sanjeev, K., Swami and Ritu Banerjee. 2013. Comparison of hospital-wide and age and location - stratified antibiograms of S. aureus, E. coli, and S. pneumoniae: age- and location-stratified antibiograms. Springer Plus, 2: 63.

Sayan Bhattacharyya, Asim Sarfraz, Mohammad Aftab Alam Ansari and 
Nitesh Jaiswal. 2015. Characterization and antibiogram of Uropathogenic Escherichia coli from a tertiary care hospital in Eastern India. Int. J. Curr. Microbiol. App. Sci., 4(2): 701-705.

Shanthi, J. and Kayathri, S. 2012. Incidence, distribution and antibiogram of uropathogens isolated from patients with urinary tract infections. Adv. Appl. Sci. Res., 3(6): 3410-3414.

Siddarth, B., Surwonse and Kelamani Chandrakanth, R. 2017. Prevalence and antibiotic susceptibility pattern of $E$. coli isolates from clinical samples of Gulbarga city, India. Int. J. Pharm. Bio.
Sci., 8(2): 479-483.

Vijeta Sharma, Geeta Parihar, Vijaylaxmi Sharma, Harshita Sharma. 2015. A Study of Various Isolates from Pus Sample with Their Antibiogram from Jln Hospital, Ajmer. J. Dent. Med. Sci., 14(1): 64-68.

Yashwant Kumar, Shivani Sood, Anshu Sharma and Kavaratty Raju Mani. 2013. Antibiogram and characterization of resistance markers among Escherichia coli Isolates from urinary tract infections. J. Infect. Dev. Ctries., 7(7): 513-519.

\section{How to cite this article:}

Mita D. Wadekar and Sathish, J.V. 2017. Changing Antimicrobial Susceptibility Pattern of $E$. coli Isolated from Urine and Pus Samples. Int.J.Curr.Microbiol.App.Sci. 6(7): 2504-2511. doi: https://doi.org/10.20546/ijcmas.2017.607.355 